\title{
Accountable to Whom?: The Use of Media to Communicate Educational Accountability to Latino Families in a California Middle School
}

¿Responsable a quién y cómo ?: El uso de los medios para comunicar las calificaciones de exámenes estatales en una escuela secundaria de California

\section{Sera Jera Hernández ${ }^{1}$}

\begin{abstract}
This paper explores how one Title I middle school in California responds to high-stakes accountability during an era of educational reform, and how one first-generation Latino immigrant family comes to understand the school's focus on test scores, high expectations, and academic achievement. Drawing from a larger Language Socialization study that utilizes participation observation and interview data, the paper provides ethnographic snapshots to demonstrate the ways in which one school communicated under, with, and through high stakes educational reform policies via a variety of media while functioning under Program Improvement status, and how the focal family participated in and negotiated these draconian educational policies that became part of their everyday experience with schooling in the U.S.
\end{abstract}

Keywords

Latino families, Educational reform policies, Standardized tests, High-stakes accountability.

\section{Resumen}

Este manuscrito explora cómo una escuela secundaria de Título I en California responde a una responsabilidad de alto impacto durante una era de reforma educativa, y cómo una familia Latina de inmigrantes de primera generación entiende el enfoque de la escuela en calificaciones de exámenes, altas expectativas y logros académicos. A partir de un estudio más amplio de Language Socialization que utiliza observación participante y datos de entrevistas, el manuscrito proporciona imágenes etnográficas para demostrar las formas en que una escuela se comunicó debajo de, con y a través de políticas de reforma educativa de alto impacto por una variedad de medios mientras funciona debajo del estado del Program Improvement, y cómo la familia focal participó y negoció estas políticas educativas draconianas que se convirtieron en parte de su experiencia cotidiana con la educación en los Estados Unidos..

\section{Palabras clave}

Familias Latinas, políticas de reforma educativa, exámenes estandarizados, responsabilidad de alto impacto. 


\section{Introduction}

Since the turn of the $21^{\text {st }}$ century, federal education reform policies have strongly shaped the essence of schooling in the United States. Hard-wired into the educational imagination are pervasive discourses of «accountability» and «high standards» where teaching to a test or narrowing a school's curriculum are the modus operandi for public school survival, particularly in linguistically and culturally diverse schools. Undoubtedly, the accountability provisions of No Child Left Bebind (NCLB) have shed light on the educational plight of historically underserved students, but those same provisions have resulted in the over-testing of English Learners (Zacher Pandya, 2011), a narrowing of school curriculum and teaching-to-the-test practices (Menken, 2006), and interventionist parent involvement initiatives that target non-dominant communities (Baquedano-López, et al., 2013). The Every Student Succeeds Act (ESSA) of 2015 revised some of the provisions of NCLB, mostly providing more control to states rather than the federal government in keeping schools «accountable.» Still, we can't ignore that educational policies play a role in what does and does not happen in schools and which classrooms receive federal monies, as national and state legislation shape the academic content, pedagogy, and curricular materials utilized with children in the pre-K-12 setting. Educational policy under an era of reform also influences practices and processes outside of schools, including how families and schools interact. Even with efforts to learn from the consequences of draconian policies of the past and present, we are currently still operating under an educational era that continues to call for and fetishize the high academic performance of low-income students of color on standardized tests in U.S. public schools.

This is particularly the case for Latino students, now the majority in California (Kane, 2010), with more than 3.2 million attending a California public school (Ramanathan, 2010). The vast majority of Latino students in California are of Mexican descent, and they continue to experience the lowest academic attainment than any other ethnic-minority group in the United States (Gándara, 1995; Yosso \& Solórzano, 2006). This paper draws from a two-year Language Socialization (Garrett \& Baquedano-López, 2002; Shieffelin \& Ochs, 1986) study that examines how federal and state language and educational policies are made sense of and get taken up by four Mexican first-generation (im)migrant families, both parents and their children, and the ways in which they make sense of educational opportunities and inequities in light of such educational policy implementation and practice. The focal families participated in the study as they navigated a public middle school in a northern or southern California school district, chosen because middle school is a critical transition-a time of increased academic vulnerability in which educational gaps tend to become more salient for Spanish-speaking students (Thomas \& Collier, 2003). Specifically, this paper explores how one Title I middle school responds to high-stakes accountability, detailing school policies and practices that are in place as a response to educational reform, and how one focal family comes to understand the school's focus on test scores, high expectations, and academic achievement. The paper begins with a brief introduction to the study's theoretical frame, methods, ethnographic context, description of the focal family, followed by ethnographic snapshots to demonstrate the ways in which one school communicated under, with, and through high stakes educational reform policies while functioning under Program Improvement ${ }^{2}$ status, and the ways in which one family participated in and negotiated educational accountability within the local middle school.

\footnotetext{
2 Program Improvement (PI) status was a status that schools that receive state funding would be designated if sub-groups of their student population did not make required growth on state exams. PI status will be explained further in the manuscript. It is important to note that with the passage of the Every Student Succeeds Act (ESSA) that reauthorized the Elementary and Secondary Education Act (ESEA) in December 2015, U.S. states have greater flexibility in developing their state plans and systems for holding schools and Local Educational Agencies (e.g., school districts) accountable for student progress, thus ending the PI movement after the 2016-17 school year (California Department of Education, 2018).
} 


\section{Theoretical framework}

Communicative practices, perspectives, and identities are developed and shaped across multiple domains within an individual's milieu. The larger study from which this paper is drawn was concerned with how first-generation mixed-status (im)migrant families come to understand the educational system in the U.S. as shaped by their interactions within and across home, school, and community contexts. Therefore, the study relied on the theoretical tenets and methodological orientations of the field of Language Socialization (Garrett \& Baquedano-López, 2002; Shieffelin \& Ochs, 1986). As an interdisciplinary approach to learning, Language Socialization (LS) blends core tenets of anthropology, sociolinguistics, and developmental psychology to study the lifelong process of acquiring language and culture simultaneously. LS research builds on sociocultural perspectives of learning (Vygotsky, 1986; Rogoff, 1991) that have demonstrated how individual consciousness is built through relations with others, and more specifically, how language is developed through the social environment. That is, LS scholars strive to understand how individuals are socialized through and to language, concerned with not only the product of interactions (i.e., language development, cultural ways of being, identities) but also the process in which that learning occurs. More specifically, it is not just the acquisition of language and culture simultaneously, but the ways in which this learning is manifested in context and with whom this learning takes place. Special attention to the nuances in language use allowed for the larger study to document the socialization of focal parents into particular school roles, linguistic and academic identities of focal students, and the complications around marginalized and empowered identities as parents and students within schools under an education reform regime. While it is also understood that individuals become indoctrinated into a way of life through their childhood language socialization experiences (that may involve one or more languages), the process of language socialization also occurs as people become members of new communities and learn new languages or varieties throughout the lifespan. It is with this in mind that the study examined middle school as a formative time in a student's life.

\section{Methods}

This study utilized the methodological tools from the field of Language Socialization (Shieffelin \& Ochs, 1986) and multiple case study (Yin, 2009) to combine the ethnographic method of sustained participation observations in focal family homes and schools with interviews of parents, students, teachers, and administrators across the four cases. Combining case study research with an ethnographic Language Socialization study allowed for multiple sources of evidence (Yin, 2009) to enhance the data collected and provide a layered description of the sociocultural and political context of the study. While the micro-level analyses of audio- and video-recorded familial talk in the four focal homes and interviews are privileged in this study, fieldnotes, documentation, archival records, and educator interview transcripts supported a robust description of documented phenomena.

\section{Ethnographic context}

Located in the southern region of the state, Valley Unified $^{3}$ is one of the largest suburban school districts in California. The district serves more than 25,000 pre-k-12 students across five cities, has a large adult education program, and 31 neighborhood schools. Two of the larger study's focal families lived in Palms, a predominantly residential city spanning a little over 3 square miles, with small sections of commercial and industrial land. Roughly 40,000 people live in the Palms community, with $90 \%$ identifying as

3 All names used in this paper are pseudonyms. 
Hispanic/Latino (US Census, 2010). With a large Spanish-speaking population, many names of the retail (especially grocery) stores, billboards, and bus stop advertisements in the area are in Spanish.

Valley Unified is located in a hypersegregated ${ }^{4}$ community that serves predominately Latino and Asian populations, with railroad tracks largely dividing the schools so that students are segregated by race and class. The two families in Valley Unified live on the low-income Latino side of the tracks and attended South West Middle School, which during the study had a 98\% Latino student population. The other side of the tracks serves a largely upper-middle class community of Asian descent. The Palms community is a mix of recent (im)migrants mostly from Mexico and Latino families that have lived there for generations. South West Middle serves almost 600 seventh and eighth grade students that live in Palms.

\section{The Fuentes family}

This paper centers on the experiences of the Fuentes family, led by single-mother Rebecca who has three daughters-16-year-old Amaya, 12-year-old Victoria, and 10-year-old Olivia. Victoria is the focal student of the study as she attended South West Middle School. Rebecca was a frutera at the local Chase bank on the weekends, selling fruit to the bank customers. She also watched her cousin's two-year-old daughter during the day, and worked as a housekeeper on Thursdays. She received federal assistance for her three daughters and was able to provide them with food and their basic needs with this support. Home observations were conducted when the family lived across the street from South West Middle. Their living space consisted of one cordoned off room in someone's house, where the family shared one bed and washed the dishes in the bathroom sink. The following analysis of South West Middle's Back to School Night (B2SN) event held at the beginning of the academic school year (2011-2012) includes a compilation of excerpts from interviews and ethnographic fieldnotes to take up some of the key issues surrounding educational accountability addressed in the principal's presentation and overall experiences the Fuentes Family had that evening and throughout the study.

\section{Back to school night at South West Middle: An ethnographic snapshot}

Federal and state education and language policies are authoritative forces in shaping the conditions surrounding U.S. public education, and consequently, the home-school relationship. Part and parcel of these policies are an educational discourse that shapes the ways in which social actors organize their daily routines in schools, influencing their interpretation and enactment, and the resultant educational programs and practices. This is strikingly the case in my experiences shadowing the Fuentes Family at South West's Back to School Night (B2SN) at the beginning of Victoria's $8^{\text {th }}$ grade year. At the time, the Fuentes family lived on the same street as the school, just a couple of blocks west. I met up with the family at their house fifteen minutes before the event started so we could walk to the school together. Many families were walking inside the school as we approached the red brick building. As a neighborhood school, there was not an issue with parking as many of the families walked to and from the school. Victoria ran off with one of her friends who also attended the school as Rebecca and I made our way to the gated entrance. A large white banner was draped in the middle of the building with the school's current Academic Performance Index (API) score and the school's goal API score (see Image 1). Academic Performance Index is the cornerstone of California's Public Schools Accountability Act of $1999^{5}$ that measures the academic

\footnotetext{
4 Experience of extreme segregation on many dimensions experienced by a racial or ethnic group (Massey \& Denton, 1989).

5 Recently the state of California swapped the numeric scores of school accountability for a color-coded system that «shows how districts and schools are performing on test scores, graduation rates and other measures of student success» (California Department of Education, 2017). The last API report for the state was presented in 2013 .
} 
performance and growth of schools on a variety of academic measures (California Department of Education, 2013a). States use standardized assessments to measure students' knowledge in English-Language Arts and Math in grades second through eight and once between grades ten and twelve. Student progress must be tracked through a disaggregation of assessment data across student subgroups determined by -socioeconomic status, gender, race, ethnicity, disabilities, and levels of English proficiency (U.S. Department of Education, 2013). A school's API is based on a numeric scale ranging from 200 to 1000.

\section{Image 1.}

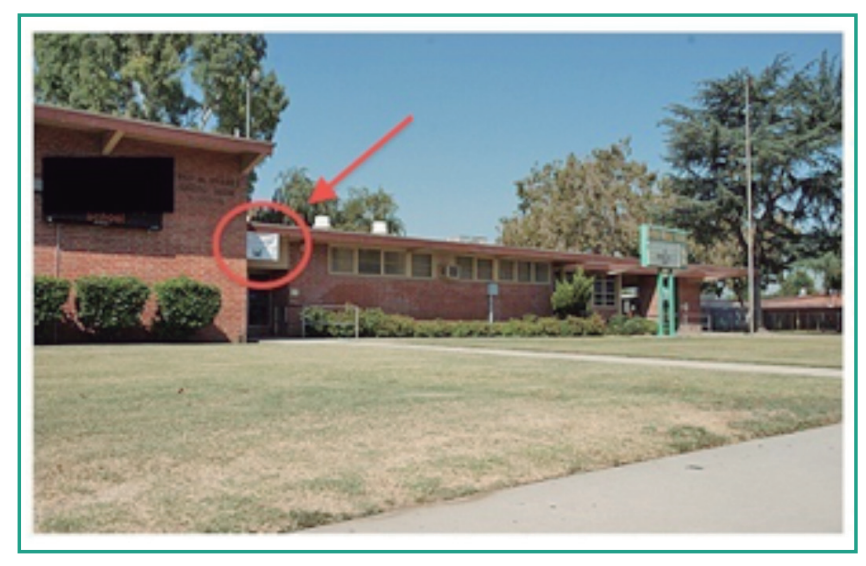

Image 1: South West Middle students are reminded of the importance of test scores each time they enter the school. A large white banner is hung above the entrance of the cafeteria that states the school's current API score and the goal API score.

Students in black South West t-shirts were handing out maps of the school. A female student from SWMS walked up to me and Rebecca, handed us a map of the school, and explained to us in Spanish how to use the map when it was time to visit the classrooms. Another student explained in Spanish that the event was starting with a presentation in the cafeteria. Image 2 is a photo of Victoria Fuentes wearing the black t-shirts the middle school students were wearing at Back to School Night at SWMS. On the front of the shirt in small black font is the school's current API score with the goal API score on the back.

\section{Image 2. Academic Performance Index - Current and Goal Score}

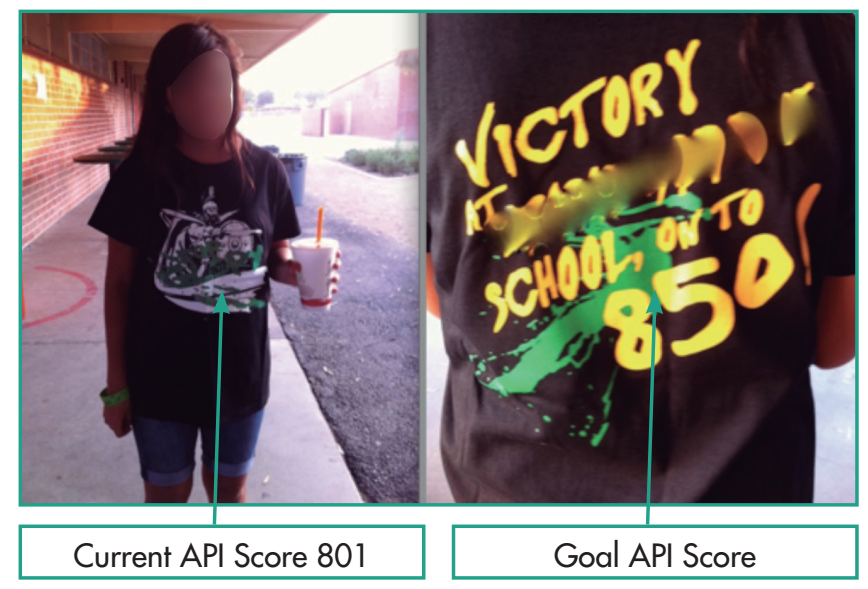

Rebecca and I walked into the packed cafeteria as the presentation was just beginning. In the back of the room was a rectangular-shaped table with a sign-in sheet. Rebecca quickly signed-in and then made her way around people standing in the back of the cafeteria. She proceeded to make her way to one of the cafeteria tables that had just enough room for us to squeeze in and sit. Roughly 150 adults, some 
with small children, were sitting at one of the cafeteria tables or standing in the back of the classroom listening to the school officials speak. Though race and ethnicity couldn't be determined from this school event observation, it appeared that most of the parents/guardians were of Latino. Most of the middle school students that came to the event with their families were outside in the quad area where Jamba Juice smoothies and snacks were being sold as a school fundraiser.

Principal Adams, a Caucasian woman in her late thirties, stood in front of the stage with a projector screen behind her. The title slide projected on the screen read, «Annual Title I Meeting for Parents» in large font with «Required By: No Child Left Behind» directly below in a smaller font size. There are quotations around «No Child Left Behind» (see Image 3 below). Rebecca turned to me and asked me in Spanish, «¿Qué significa No Child Left Behind?» as she slowly read it off the screen. I briefly explained to her in Spanish that it was a government policy in education. I told her that schools are required to meet the educational needs of all students as determined by their standardized test scores because of the policy.

Image 3. Accountability at South West Middle

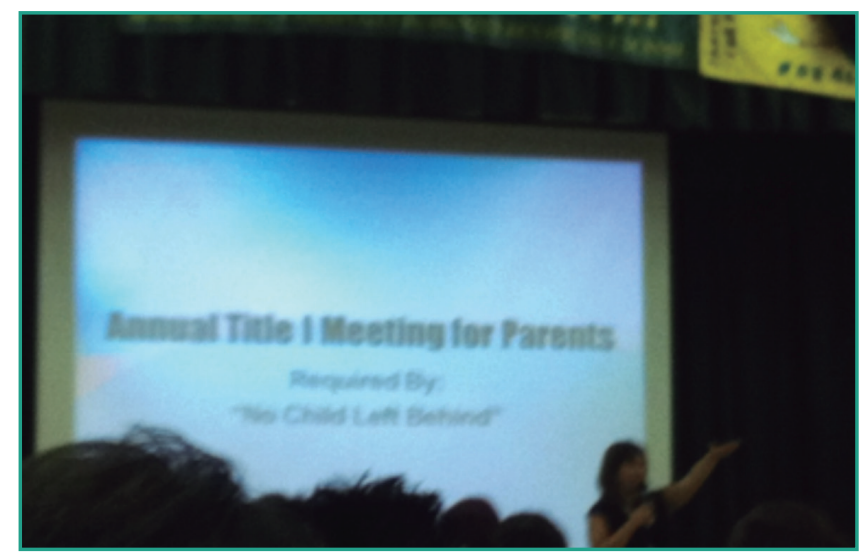

Image 3: Principal Adams executes a two-for-one parent meeting by combining a Back to School Night event with an annual Title I meeting required by NCLB. The presentation was given in English though the auditorium was filled with Spanishspeaking families. Rebecca asked me to translate for her during the meeting as she did not understand what the principal was sharing.

Principal Adams spoke in English and the families sat quietly giving her their undivided attention. It was not clear if the families understood her or not, but Rebecca asked me to translate for her throughout. Principal Adams began her Back to School Night (B2SN) event with a presentation on an educational provision of No Child Left Behind - Title I, Part A - Improving the Academic Achievement of the Disadvantaged. Title I, Part A, was an original provision of the Elementary and Secondary Education Act of 1965, to allocate funding to schools and districts with at least $35 \%$ of the student population deemed «disadvantaged» as determined by low-income indicators (U.S. Department of Education, 2011). The purpose of Title I, Part A is two fold - to provide extra funding to schools that serve high-poverty communities and keep states, districts, and schools accountable for student academic achievement and standards-based instruction. Though Title I funding must target low-income students, all students at a Title I school are eligible to benefit from such monies ${ }^{6}$.

6 Schools may use Title I funds, as well as other federal, state, and local funds, to operate a «schoolwide program» to improve the instructional program for all students within the school. Title I schools with less than the 40 percent schoolwide threshold or that choose not to operate a schoolwide program offer a «targeted assistance program» in which the school identifies students who are failing, or most at risk of failing, to meet the state's challenging academic achievement standards. Targeted assistance schools design, in consultation educational stakeholders, an instructional program to meet the needs of those students. Both schoolwide and targeted assistance programs must use instructional strategies based on scientifically based research and implement parental involvement activities (U.S. Department of Education, 2011). 
Since South West Middle receives Title I funding, they are required to provide this information to parents and meet additional requirements noted in the provision ${ }^{7}$. Schools receiving Title I funds are also required to hold an annual meeting to inform parents of their school's participation in the development of the parent involvement policy and explain to parents their rights in the development and approving of the policy (U.S. Department of Education, 2004). This was not something covered by Principal Adams in her presentation, but she did cover other requirements of the provision. She explained what Title I entails, who qualifies, whether Title I programs need to show results, and the school's responsibilities as a school receiving Title I funds. She talked through a PowerPoint slide on parent responsibilities under Title I that included the following bulleted list:

- Attend meetings (parent-teacher conferences)

- Reinforce the school expectations

- Call the school or find out what is going on

- Set goals with their children to help them achieve their goals

- Attend all school events

She included a slide with a list of options for parents to consider when getting involved but not much explanation of what each entailed.

- School Site Council

- English Learner Advisory Committee

- Parent Booster

- Family Fiesta

- After School Education and Safety program (ASES)

The Parent Booster was the cooking class the parents have every Friday, the Family Fiesta was a oneday event where students play kickball against teachers in a local park while the administrators barbecue for the families, and ASES is an afterschool program that is sponsored with federal money that provides, afterschool care, homework assistance, and enrichment activities such as sports. All three of the administrators (the principal, vice-principal from school year 2010-2011 and vice-principal from 2011-2012) reported in interviews that the cooking class (Parent Booster) was the way in which parents were involved on campus. Parents take turns cooking meals, others come to learn and take the recipe. At lunch, the teachers buy the meals and some of the money is used as a fundraiser for the students.

It is noteworthy that Principal Adams shared a Title I presentation during an event where many parents were present (i.e., B2SN). To be in compliance with the federal provision, a certain number of parents must be present at the annual Title I meeting. Choosing to hold the meeting during an event where many parents attend so they can meet their children's teachers and visit their classrooms was strategic. The move could have served as a maneuver for the administration to check the annual Title I parent meeting off their list. Another possible explanation could be that the administration wanted as many parents to hear about the Title I provision so they could be informed on their rights and responsibilities as a parent of a child in a Title I middle school, knowing there is usually a larger turnout for events like B2SN.

See Henderson (2002), for the six key leverage points for parent involvement in NCLB Section 1118 through which schools and districts receiving Title I funds must abide. 
After sharing the Title I slides, Principal Adams segued into a discussion about Academic Performance Index ranks. She began with the school's API score and ranking by explaining that she had been at the school for 11 years and the API was 484 when she started as the vice-principal. Two school years ago South West's API score was 807 and last year it was 829. She lauded the teachers for their tireless efforts in working with the students. Principal Adams then detailed how compared to similar schools, that is, schools with similar student demographics and teacher education levels to that of South West, they have scored a 10. She does not expand on the demographics in which she is referring though. In addition to API scores, schools are also ranked on a scale from 10 (highest) to 1 (lowest). A school's «statewide» API rank compares its API to the APIs of all other schools statewide of the same type. A school's «similar schools» rank compares its API to the APIs of 100 other schools of the same type that have similar educational opportunities and challenges (California Department of Education, 2013a). Image 4 is taken from the California Department of Education's website which illustrates the difference between stateside API ranks and what is called similar schools rank.

\section{Image 4. API Ranks from California Department of Education}

\begin{tabular}{ll}
\multicolumn{1}{c}{ Statewide Ranks } & \multicolumn{1}{c}{ Similar School Ranks } \\
\hline - Calculated separately by school type (elementary, middle, & - Calculated separately by school type (elementary, middle, \\
$\begin{array}{ll}\text { or high school } & \text { or high school } \\
\text { - School's API compared to all other schools in the state } & \text { - School's APl compared to } 100 \text { other schools of the same } \\
\text { of the same type } & \begin{array}{l}\text { type that have similar educational opportunities and } \\
\text { challenges }\end{array} \\
\end{array}$ \\
\hline
\end{tabular}

Schools must make Adequate Yearly Progress (AYP) as determined by their individualized goals for students' scores on standardized achievement tests which depends on student demographics and a school's student subgroups (California Department of Education, 2013b). Specifically, to meet AYP, schools must meet four requirements: (1) student participation rate on statewide tests; (2) percentage of students scoring at the proficient level or above in English-language arts and Mathematics on statewide tests; (3) Growth API; and (4) graduation rate (if grade twelve students are enrolled). When a Title I school fails to make Adequate Yearly Progress (AYP), it is placed in Program Improvement (PI). Schools are eligible to exit PI if they make AYP for two years in a row. By federal law, it is only the Title I funded schools that are at risk of being labeled as in need of improvement, and when AYP is not met, these schools may go through restructuring and/or a reduction in funding (Yell \& Drasgow, 2005).

Under Program Improvement status, SWMS tracked their students into «pathways.» As mentioned in an interview with Victoria's English-Language Arts teacher Ms. Lim:

This year, it depends on what class, because this school does track the students, and so there's different groups. Like you have the honors kids, the AVID kids. You have the kids who have double either Math or double Language Arts or even both, double Math and Language Arts. And then I also have one group that's RSP setting, which is the Special Ed kids, and so it's different. Every class is extremely unique.

In this excerpt from our interview, Ms. Lim foregrounds South West's pathways because it played a big role in determining the «type» of students in any of her courses. As a reflection of society, school are

\footnotetext{
RSP is an acronym for Resource Specialist Program. As a regulation of the U.S. Department of Education's Individuals with Disabilities Education Act (IDEA), students with special needs are required to received Special Education services through Special Education classes or in the mainstream classroom with extra support from a Resource Specialist as determined by their Individualized Education Plans (U.S. Department of Education, 2006).
} 
hierarchical and stratified in nature, though educational research has long promoted the ideal of giving students equal access to knowledge (Goodlad \& Oakes, 1988). A contentious practice, ability grouping and implementation of a differentiated curriculum has a long history in U.S. schools. Specifically, tracking has been documented as an educational practice that reproduces school-based inequities by not providing access to core knowledge, experiences, and material that students need to be successful along their educational trajectory (Oakes, 1987). Because of that, many schools try to avoid such differentiated structures when they strive to serve all students, regardless of their previous experiences and abilities, though de-tracking as a goal is not always realized in schools (Gamoran \& Weinstein, 1998). Students of color and students from low socioeconomic statuses are the most negatively affected by tracking and ability grouping (Apple, 2001).

The practice of scheduling courses based on standardized tests disproportionately affects schools receiving Title I funding, like SWMS, that must make their adequate yearly progress. Thus, schools serving low-income students are most at risk of narrowing their curriculum and course offerings as a response to federal educational policies that punish schools based on their students' standardized test scores. Trying to minimize grouping or tracking has been found to be more difficult for middle and high schools (Gamoran \& Weinstein, 1998). Gamoran and Weinstein (1998) found that some teachers were able to provide high quality instruction regardless of whether the structure of the school involved de-tracking or tracking students. They posited that particular conditions were more important than school structure - intellectual rigor, commitment to equity, and the use of differentiation in a way that does not contradict equity (p. 410), all played significant roles in providing highly effective classroom instruction to students across academic levels and experiences. Still the educators at South West tracked students that were not «proficient» on state exams in Language Arts or Math into a «double» period - double the amount of class time on one or both of these academic areas. This led to the cutting of electives for students on this track.

Students were also rewarded for their performance on the California State Tests in the beginning of the school year. V.P. Smith stated in an interview:

We celebrate a lot of the testing times, so when we first started with the school year, the first month
that we started we did a medal ceremony, and we gave students who are proficient or advanced in any
of their testing a medal for either language arts or math. So they could bave two medals. Then we give
certificates for kids who place, you know, who advance 10 points or advanced 30 points. So that could
mean proficient to advanced, but that could also mean basic to proficient or below basic to basic. Just
so that we can award a lot more students.

Students are explicitly rewarded if they improve on test scores; similar to the way Title I schools are rewarded vis-à-vis the federal accountability system. Another teacher (not in the study), quoted in an educational magazine (see Image 5) shared his belief that standardized test scores may not be the best way to evaluate schools, but the school has nevertheless, experienced some positive changes due in the last several years - a time period when they were in Program Improvement. 
Image 5. SWMS Educator Quote

"It went from being that school -
where nobody wanted to be - to the
school where everybody wants to be, and
is now considered a hidden treasure,"
says "We may not buy into the
argument that test scores are the way in
which schools should be judged, but the
school's scores are now stellar (in the
800 ). Teachers have earned the right to
do it their way."

Image 5: In an educational magazine article, a teacher at South West alludes to the positive changes at South West that made them a "hidden treasure" in the district.

Educational research suggests that low-income and ethnically and linguistically diverse students are more likely to have lowered expectations for their academic achievement (Darling-Hammond, 1995; Olneck, 1995). The climate at South West Middle appears to be the opposite - a collective ideology of high expectations for all students, with academic structures and supports in place for those who need it. Course offerings, however, are driven by state standardized tests, as a result of high-stakes policies (i.e., Title I, Part A) that placed South West in Program Improvement (PI) ${ }^{9}$. Doubles in Language Arts and Math the courses that impact AYP and API scores - were not an educational remedy at South West before the school went into PI status. This schoolwide educational intervention may play a role in students performing better on the state tests. The question remains whether students on the remedial tracks are negatively affected in the short or long-term. Teacher expectations play a significant role in students' educational outcomes (Levine \& Lezotte, 1995), where children at a very young age are able to determine which students are considered smart depending on how the teacher interacts with them (Weinstein, Marshall, Sharp, \& Botkin, 1987), and which groups or classes they are assigned (e.g., the remedial class, the low reading group, or «doubles» as in the case of South West).

\section{Conclusion and implications}

This paper utilized ethnographic snapshots to demonstrate the ways in which one school communicated under, with, and through high stakes educational reform policies while functioning under Program Improvement status, and the ways in which one family participated in and negotiated those experiences with the school. High-stakes educational tests and related accountability practices impact the daily experiences of low-income students and their parents. No Child Left Behind tackles issues of school and student failure, and takes up a moral narrative that promotes high expectations for all students regardless of their social status. Through these grounding principles, NCLB has created a climate of accountability via high-stakes testing among public school educators and students in districts and schools nation-wide, where a centralized approach to education is governed by federal rewards and sanctions (Darling-Hammond, 2004; Hunter \& Bartee, 2003). Increased centralization of government in local educational decision-making inevitably impacts parents and their students. Based on standardized test scores, students at South West

$9 \quad$ NCLB requires that all students are proficient in Language Arts and Math by the 2013-2014 school year though some states applied for flexibility with this provision. California was not one of those states. 
were placed on academic paths that dictated the academic courses offered to them, playing a role in shaping the educational identities of students and their long-term educational opportunities. There is strong consensus that effective schools hold high expectations for educational achievement for all students with a clear vision of what educational achievement entails, regardless of program models (Gandara, 1995s). More so than ever, high stakes standardized test performance influences schools' goals and visions of education and may be their prime educational achievement standards. When a discourse of high expectations, and the educational practices that ensue, translate to the narrowing of school curriculum and teaching-to-the-test practices, no one loses more than our students.

It was evident in this study that top-down high-stakes educational reform influenced the Fuentes Family's perspective of U.S. public schooling. Educational studies tend to focus on how structures and organizations play a role in policy implementation at the school and classroom level and the impact such practice has on student academic achievement (Coburn, 2004; Honig, 2006). Educators' responses to federal provisions that promote high-stakes accountability saturate the media and national conversation on education, yet little is known on how Latino immigrant families interpret, discuss, or even enact such government policies. The ramifications of policies that ensue from the Elementary and Secondary Education Act, and later iterations of federal reforms efforts (i.e., NCLB, Race to the Top, Elementary Student Succeeds Act $)$ must be studied beyond the walls and institution of the school to consider and document how such initiatives trickle down to experiences within families' homes and private lives, influencing families' worldviews and students' academic identities.

\section{Bibliographic references}

Apple, Michael W. (2001). "Markets, Standards, Teaching and Teacher education". Journal of Teacher Education, $52(3), 182-96$.

Baquedano-López, Patricia; Alexander, Rebecca Anne \& Hernandez, Sera Jera (2013): "Equity Issues in Parental and Community Involvement in Schools: What teacher educators need to know". Review of Research in Education, 37 (1), 149-182.

Bourdieu, Pierre (1977). Outline of a Theory of Practice. Cambridge: Cambridge University Press.

California Department of Education. (2018). Program Improvement Status Determinations. Available from https://www.cde.ca.gov/ta/ac/ay/tidetermine.asp.

California Department of Education. (2017). California School Dashboard. Available from https://www. caschooldashboard.org/\#/Home.

California Department of Education. (2013a). Academic Performance Index. Available from http:// www.cde.ca.gov/ta/ac/ap/.

California Department of Education. (2013b). Adequate Yearly Progress. Available from http://www. cde.ca.gov/ta/ac/ay/.

Coburn, Cynthia. E. (2004): "Beyond Decoupling: Rethinking the Relationship Between the Institutional Environment and the Classroom”. Sociology of Education, 77, 211-244.

Darling-Hammond, Linda (1995): "Inequality and access to knowledge" in James A. Banks \& Cherry, A. McGee Banks (eds.): Handbook of Research on Multicultural Education. New York: Macmillan. 
Darling-Hammond, Linda (2004): "Standards, accountability, and school reform". Teachers College Record, $106(6), 1047-1085$.

Gamoran, Adam, \& Weinstein, Matthew (1998): "Differentiation and opportunity in restructured schools". American Journal of Education, 106, 385-415.

Gándara, Patricia (1995). Over the Ivy Walls: The Educational Mobility of Low-income Chicanos. Albany: State University of New York Press.

Garrett, Paul B., \& Baquedano-López, Patricia (2002): "Language Socialization: Reproduction and Continuity, Transformation and Change". Annual Review of Anthropology, 31, 339-361.

Giddens, Anthony (1979). Central Problems in Social Theory: Action, Structure, and Contradiction in Social Analysis. Berkeley, CA: University of California Press.

Goodlad, John I., \& Oakes, Jeannie (1988): "We Must Offer Equal Access to Knowledge". Educational Leadership, 45 (5), 16-22.

Henderson, Anne T. (2002). No Child Left Bebind: What's in it for Parents? A Guide for Parent Leaders and Advocates. Washington, D.C.: Parent Leadership Associates.

Honig, Meredith I. (ed.) (2006). New Directions in Education Policy Implementation: Confronting Complexity. New York: State University of New York Press.

Hunter, Richard C., \& Bartee, RoSusan. (2003): "The Achievement Gap: Issues of Competition, Class, and race". Education and Urban Society, 35 (2), 151-160.

Kane, W. (2010): Latino Kids Now Majority in State's Public Schools. SF Gate. Retrieved from http:// www.sfgate.com/education/article/Latino-kids-now-majority-in-state-s-public schools-3166843.php.

Levine, Daniel U., \& Lezotte, Lawrence.W. (1995): "Effective Schools Research" in James A. Banks \& Cherry A. Mcgee Banks (eds.): Handbook of Research on Multicultural Education. New York: Macmillan.

Massey, Douglass S., \& Denton, Nancy A. (1989). "Hypersegregation in U.S. metropolitan areas: Black and Hispanic segregation along five dimensions". Demography, 26(3), 373-391.

Menken, Kate (2006): “Teaching to the Test: How No Child Left Behind Impacts Language Policy, Curriculum, and Instruction for English Language Learners”. Bilingual Research Journal, 30 (2), 521-546.

Oakes, Jeannie (1987) :“Tracking in Secondary Schools: A Contextual Perspective”. Educational Psychologist, 21 (2), 129-54.

Olneck, Michael R. (1995): "Immigrants and Education" in James A. Banks \& Cherry A. Mcgee Banks (eds.): Handbook of Research on Multicultural Education. New York: Macmillan.

Ramanathan, A. (2010, November 17). "When Minorities are the Majority". San Francisco Chronicle. Retrieved from http://articles.sfgate.com/2010-1117/opinion/24835787_1_minority-students-latino-students-student-population.

Rogoff, Barbara (1991). Apprenticeship in Thinking: Cognitive Development in Social Context. New York: Oxford University Press.

Schieffelin, Bambi B., \& Ochs, Elinor (eds.) (1986). Language Socialization Across Cultures. Cambridge: Cambridge University Press. 
Thomas, Wayne P., \& Collier, Virginia P. (2003). "Reforming Education Policies for English learners: Research Evidence from U.S. schools" The Multilingual Educator, 4(1), 16-19.

U.S. Department of Education (2004): "Parental Involvement: Title I, Part A.” Non-Regulatory Guidance. Washington, DC: U.S. Department of Education.

U.S. Department of Education (2006). Building the legacy: IDEA 2004. Available from http://idea.ed.gov/ explore/home.

U.S. Department of Education (2011). Title I, Part A. Available from http://www2.ed.gov/programs/ titleiparta/index.html.

U.S. Department of Education (2013). Standards and Assessment Group and Accountability Group. Available from http://www2.ed.gov/admins/lead/account/saa.html.

Vygotsky, Lev (1986). Thought and Language. Massachusetts: The MIT Press.

Weinstein, Rhona S., Marshall, H. H., Sharp, L., \& Botkin, M. (1987): "Pygmalion and the Student: Age and Classroom Differences in Children's Awareness of Teacher Expectations". Child Development, 58, 1079-1093.

Yell, Michael L., \& Drasgow, Erik (2005). No Child Left Behind: A Guide for Professionals. Upper Saddle River, NJ: Pearson.

Yin, Robert K. (2009). Case Study Research: Design and Methods (4 $4^{\text {th }}$ Ed.). Thousand Oaks, CA: Sage.

Yosso, Tara J. \& Solórzano, Daniel G. (2006). "Leaks in the Chicana and Chicano Educational Pipeline". Latino Policy \& Issues Brief, 13.

Zacher Pandya, Jessica (2011). Overtested: How high-Stakes Accountability Fails English Language Learners. New York, NY: Teachers College Press.

\section{Biographical note}

Sera Jera Hernández is a professor of Education at San Diego State University, where she teaches university courses on multilingual education, biliteracy, language policy and language development. She earned her $\mathrm{PhD}$ in Language, Literacy and Culture from the University of California, Berkeley. 